\title{
Fine root biomass and root length density in a lowland and a montane tropical rain forest, SP, Brazil
}

\author{
Bruno Henrique Pimentel Rosado ${ }^{1,2,5}$, Amanda Cristina Martins ${ }^{1,4}$, Talita Cristina Colome ${ }^{1,4}$, \\ Rafael Silva Oliveira ${ }^{1}$, Carlos Alfredo Joly ${ }^{1} \&$ Marcos Pereira Marinho Aidar ${ }^{3}$ \\ ${ }^{1}$ Departamento de Biologia Vegetal, IB, Universidade Estadual de Campinas - UNICAMP, \\ Campinas, SP, Brazil, www.ib.unicamp.br/dep_botanical \\ ${ }_{2}^{2}$ Instituto de Pesquisas Jardim Botânico do Rio de Janeiro, \\ Unidade de Botânica Sistemática, Rua Pacheco Leão, 915, Jardim Botânico, CEP 22460-030, \\ Rio de Janeiro, RJ, Brasil, www.jbrj.gov.br/ \\ ${ }^{3}$ Seção de Fisiologia e Bioquímica de Plantas, Instituto de Botânica, SP, Brasil, \\ http://www.ibot.sp.gov.br/index.php \\ ${ }^{4}$ Pontifícia Universidade Católica de Campinas - PUC, Centro de Ciências da Vida, \\ Faculdade de Ciências Biológicas, Campinas, SP, Brasil, http://www.puc-campinas.edu.br/ \\ ${ }^{5}$ Corresponding author: Bruno Henrique Pimentel Rosado,e-mail: brunorosado@gmail.com
}

ROSADO, B.H.P., MARTINS, A.C., COLOMEU, T.C., OLIVEIRA, R.S., JOLY, C.A. \& AIDAR, M.P.M. Fine root biomass and root length density in a lowland and a montane tropical rain forest, SP, Brazil. Biota Neotrop. 11(3): http://www.biotaneotropica.org.br/v11n3/en/abstract?article+bn03411032011

\begin{abstract}
Fine roots, $<2 \mathrm{~mm}$ in diameter, are responsible for water and nutrient uptake and therefore have a central role in carbon, nutrient and water cycling at the plant and ecosystem level. The root length density (RLD), fine root biomass (FRB) and vertical fine root distribution (VRD) in the soil profile have been used as good descriptors of resource-use efficiency and carbon storage in the soil. Along altitudinal gradients, decreases in temperature and radiation inputs (depending on the frequency of fog events) may reduce decomposition rates and nutrient availability what might stimulate plants to invest in fine roots, increasing acquisition of resources. We evaluated the seasonal variation of fine root parameters in a Lowland and Montane forest at the Atlantic Rain Forest. We hypothesized that, due to lower decomposition rates at the Montane site, the FRB and RLD at soil surface will be higher in this altitude, which can maximize the efficiency of resource absorption. FRB and RLD were higher in the Montane forest in both seasons, especially at the 0-5 layer. At the 0-5 soil layer in both sites, RLD increased from dry to wet season independently of variations in FRB. Total FRB in the top 30 $\mathrm{cm}$ of the soil at the Lowland site was significantly lower $\left(334 \mathrm{~g} \cdot \mathrm{m}^{-2}\right.$ in the dry season and $219 \mathrm{~g} \cdot \mathrm{m}^{-2}$ in the wet season) than at the Montane forest (875 and $451 \mathrm{~g} \cdot \mathrm{m}^{-2}$ in the dry and wet season, respectively). In conclusion, despite the relevance of FRB to describe processes related to carbon dynamics, the variation of RLD between seasons, independently of variations in FRB, indicates that RLD is a better descriptor for studies characterizing the potential of water and nutrient uptake at the Atlantic Rain Forest. The differences in RLD between altitudes within the context of resource use should be considered in studies about plant establishment, seedling growth and population dynamics at the Atlantic Rain Forest. At the ecosystem level, RLD and it seasonal variations may improve our understanding of the Atlantic rain forest functioning in terms of the biogeochemical fluxes in a possible scenario of climate change and environmental changes.
\end{abstract}

Keywords: altitudinal variation, fine root parameters, vertical distribution of fine roots, seasonality, atlantic rain forest.

ROSADO, B.H.P., MARTINS, A.C., COLOMEU, T.C., OLIVEIRA, R.S., JOLY, C.A. \& AIDAR, M.P.M. Biomassa de raízes finas e densidade do comprimento radicular em uma floresta tropical chuvosa de terras baixas e montana, SP, Brasil. Biota Neotrop. 11(3): http://www.biotaneotropica.org.br/v11n3/pt/ abstract?article+bn03411032011

Resumo: Raízes finas, $<2$ mm de diâmetro, são as principais responsáveis pela absorção de água e nutrientes e, portanto, têm um papel central nos ciclos carbono, água e nutrientes, desde o nível da planta até o ecossistêmico. A densidade do comprimento radicular (DCR), a biomassa de raízes finas (BRF) e a distribuição vertical de raízes finas (DVR) no perfil do solo têm sido utilizados como bons descritores da eficiência no uso de recursos e de estocagem de carbono no solo. Ao longo de gradientes altitudinais, a diminuição da temperatura e da radiação solar (dependendo da frequência de eventos de neblina) podem reduzir as taxas de decomposição e disponibilidade de nutrientes, o que poderia estimular o aumento do investimento das raízes finas para maximizar a absorção de água e nutrientes. O presente estudo avaliou a variação sazonal de parâmetros radiculares nas florestas ombrófilas densas de Terras Baixas (FODTB) e Montana (FODM) na Mata Atlântica. A hipótese foi a de que o investimento em BRF e DCR seria maior na FODM, o que poderia maximizar a eficiência na absorção de recursos. A BRF e a DCR foram maiores na FODM em ambas as estações, especialmente na profundidade de $0-5 \mathrm{~cm}$. A BRF total 
nos primeiros $30 \mathrm{~cm}$ de solo na FODTB foi significativamente menor (334 g.m $\mathrm{m}^{-2}$ na estação seca e 219 g.m. ${ }^{-2}$ na chuvosa) do que na FODM (875 e 451 g.m - $^{-2}$ nas estações seca e chuvosa, respectivamente). Na profundidade de 0-5 cm em ambas as altitudes, a DCR aumentou da estação seca para chuvosa independentemente de variações na BRF. Apesar da relevância da BRF para descrever processos relacionados à dinâmica de carbono, a variação da DCR entre estações, independente de variações na BRF, indica que a DCR é um melhor descritor para estudos caracterizando o potencial de absorção de água e nutrientes na Floresta Atlântica. As diferenças da DCR entre altitudes dentro do contexto de uso de recursos devem ser consideradas em estudos sobre estabelecimento, crescimento de plântulas e dinâmica de populações na Floresta Atlântica. No nível ecossistêmico, as variações sazonais da DCR podem aumentar nosso entendimento sobre o funcionamento da Floresta Atlântica em termos de fluxos biogeoquímicos em um possível cenário de mudanças climáticas e ambientais.

Palavras-chave: variação altitudinal, parâmetros de raízes finas, distribuição vertical de raízes finas, sazonalidade, floresta tropical atlântica.

\section{Introduction}

Fine roots, defined as those $<2 \mathrm{~mm}$ in diameter, are responsible for water and nutrient uptake and therefore have a central role in carbon, nutrient and water cycling at the plant and ecosystem level (Nepstad et al. 1994, Jackson et al. 1997, Gordon \& Jackson 2000). High fine root densities increase the hydraulic contact between plants and the soil, water uptake rates and therefore contribute to higher transpiration rates (Nepstad et al. 1994, Williams et al. 1998) and embolism repair (Zeppel et al. 2004). In addition, $60 \%$ of the carbon fixed in annual basis is allocated belowground (Jackson et al. 1996, 1997) and the amount of carbon and nutrients returned to the soil via decomposition of fine roots may be equal or higher in comparison to leaves (Jackson et al. 1997).

Root length density (RLD), the total root length per unit soil volume, has been used as a good descriptor of resource use efficiency and may indicate the potential of water and nutrient uptake of a vegetation stand (Soethe et al. 2006). Fine root biomass (FRB) is an important parameter related to carbon allocation and carbon turnover at the ecosystem level (Nepstad et al. 1994, Jackson et al. 1997). The evaluation of vertical fine root distribution (VRD) in the soil profile indicates (i) the plant's resource use capacity in soil; (ii) the efficiency to avoid nutrient losses by leaching (Nepstad et al. 1994, Soethe et al. 2006); (iii) and fine root's contribution to biogeochemical cycles (Jackson et al. 1996).

Along altitudinal variations in tropical forests, the investment in fine roots tend to increase in response to changes of different environmental factors such as radiation, temperature and nutrient availability in soil (Soethe et al. 2006, Leuschner et al. 2007, Graefe et al. 2008). In tropical montane forests, the lower temperatures and lower radiation inputs (depending on frequency of fog events) may reduce the decomposition rates and nutrient availability (Bruijnzeel \& Veneklaas 1998). At higher altitudes, lower temperatures may promote the reduction in microbial nutrient mineralisation rates; mycorrhizal fungi activities and their nutrient supply functions and carrier activity in the root plasma membranes, which are temperature sensitive, leading to reductions in nutrient uptake (Leuschner et al. 2007). Thus, a higher RLD might counterbalance the lower nutrient-cycling rates allowing nutrient uptake (Soethe et al. 2006).

However, in different ecosystems, factors such as waterlogged soils, lower temperatures, reductions in trees size and species richness, might contribute to lower fine root investment (Soethe et al. 2006, Leuschner et al. 2007, Graefe et al. 2008). Curiously, although abiotic factors such as temperature, nutrient and water availability may stimulate fine root production, controversial results have been found in different studies (Gill \& Jackson 2000, Yavitt \& Wright 2001, Zobel et al. 2007). For instance, seasonal variations and increases in RLD were not observed along an altitudinal gradient from 1900 to $3000 \mathrm{~m}$ at tropical forests in Ecuador (Soethe et al. 2006).
However, increases in fine root dynamics (root length production and root turnover) have been observed along an altitudinal gradient, from 1050 to $3060 \mathrm{~m}$, at the South Ecuadorian mountain rainforests (Graefe et al. 2008).

In the present study, we evaluated the variation of fine root parameters at the Atlantic Rain Forest in two altitudes ( 100 and $\sim 1000 \mathrm{~m}$ above sea level) in the wet and dry seasons. Despite the importance of fine roots in different scales, the difficulties associated with sampling and evaluation of different factors affecting fine roots parameters (e.g species composition, soil moisture, nutrient and water availability, temperature and soil texture) result in a lack of information for different environments (Jackson et al. 1996, 1997, Gill \& Jackson 2000, Soethe et al. 2006, Leuschner et al. 2007, Graefe et al. 2008). There is scarce information about the belowground compartment in tropical forests and, especially for the Atlantic Rain Forest, which is a biodiversity hotspot (Myers et al. 2000), these data are essential to parameterize models about ecosystem functioning and plant responses to changes in climate. In the same sites where we performed our study, Sousa Neto (2008) found higher fine root biomass at the Montane forest compared with Lowland and Submontane forests, which may be related to the optimization of resource absorption due to lower decomposition rates at the Montane forest (Sousa Neto 2008, Martins 2010). However, despite findings showing that the proportion of fine roots is higher in 0-5 soil layers, optimizing relative nitrogen uptake (Soethe et al. 2006), Sousa Neto (2008) evaluated FRB on the total $10 \mathrm{~cm}$ of soil profile without distinguish 0-5 and 5-10 layers. Additionally, information about fine root parameters at the Atlantic Rain Forest on deeper soil profile is still lacking.

In this sense, the evaluation of the VRD will bring important information regarding the plant's efficiency to avoid nutrient losses by leaching and fine root's contribution to biogeochemical cycles (Nepstad et al. 1994, Jackson et al. 1996; Soethe et al. 2006) in the Atlantic Rain Forest. In addition, information about RLD is essential since it may indicate the potential of water and nutrient uptake of a vegetation stand (Soethe et al. 2006). In this study we hypothesized that (i) FRB and RLD will be higher along the soil profile in the Montane forest, which could potentially maximize resource absorption under lower decomposition rates; (ii) considering optimization of resource absorption, the proportion of fine roots will be higher at the $0-5 \mathrm{~cm}$ layer in both sites, but especially at the Montane forest due to lower decomposition rates.

\section{Material and Methods}

\section{Study sites}

Our study was conducted in lowland and montane forest in the Serra do Mar State Park, which is the largest protected area 
of Atlantic Rain Forest and covers 315,000 ha in the north of São Paulo state, Brazil. The Lowland forest is $100 \mathrm{~m}$ above sea level$\left(23^{\circ} 31^{\prime}\right.$ to $23^{\circ} 34^{\prime} \mathrm{S}$ and $45^{\circ} 02^{\prime}$ to $45^{\circ} 05^{\prime} \mathrm{W}$ ) and has a tropical climate and a mean annual precipitation of $2200 \mathrm{~mm}$. Usually, the driest months are July and August. The Montane forest is $\sim 1000 \mathrm{~m}$ above sea level - $\left(23^{\circ} 17^{\prime}\right.$ to $23^{\circ} 24^{\prime} \mathrm{S}$ and $45^{\circ} 03^{\prime}$ to $\left.45^{\circ} 11^{\prime} \mathrm{W}\right)$, has a tropical temperate climate, with mean annual precipitation around $2000 \mathrm{~mm}$ and a high fog frequency around 100 days per year (Rosado et al. 2010). All physiognomies are characterized as Ombrophylous Dense Atlantic Forest (broadleaf evergreen forest; Joly et al. 1999). Along the altitudinal variation, there is an increase of organic matter content, aluminum and nitrogen and phosphorous concentration (Martins 2010). When compared to Amazon, the soils in both sites are poor in basic cations and higher in aluminum concentration (Martins 2010).

\section{Root sampling and analysis}

In each altitude, we collected samples in fourone-hectare plots (divided in 100 sub-plots) belonging to the Gradiente Funcional/BIOTA Project whose main proposal is evaluate changes in forest composition, structure and functioning along the altitudinal variation (http://www2. ib.unicamp.br/projbiota/gradiente_funcional/index.html). In each plot we randomly chose 4 sub-plots for sampling and in each one, soil samples were taken from the following depths: 0-5, 5-10, 10-20 and $20-30 \mathrm{~cm}$. The same procedure was repeated in the dry (August 2007) and wet season (December 2007/January 2008), totalizing 128 soil samples per season. We used a soil corer with a diameter of $20 \mathrm{~cm}$ to collect samples at $0-5 \mathrm{~cm}$, and a smaller diameter corer $(10 \mathrm{~cm})$ for the other depths. Samples were labeled, taken to laboratory and kept frozen until processing to extract fine roots. The total volume of each sample was measured with a plastic container. Fine roots were separated from soil using a semi-automatic root washer system built with buckets and hoses as described by Martins (2002). After that, samples were kept in alcohol $70 \%$ until separation in living and dead roots under magnifying glass, based on colour, root elasticity and the degree of cohesion of cortex, periderm and stele (Persson 1978).

We followed the protocol suggested by Bouma et al. (2000) to acquire better digital images used to estimate fine root length and root surface area. Fine roots were stained with methylen blue and placed on a transparent tray with a thin layer of water on a flatbed scanner to acquire 400 dpi images (Bouma et al. 2000) (Figure 1). We used the Rootedge software version 2.3 to obtain root length and root surface area (Kaspar \& Ewing 1997, Himmelbauer et al. 2004). After scanning, roots were oven-dried for 72 hours and FRB was determined as dry mass/area $\left(\mathrm{g} \mathrm{m}^{-2}\right)$. For comparison with other datasets, we calculated the total FRB in the top $30 \mathrm{~cm}$ of the soil in each site/season. In addition, the FRB at both sites was normalized by total aboveground biomass (AGB), considering stems $\geq 4.8 \mathrm{~cm}$, (Alves et al. 2010). Through the FRB/AGB ratio, it is possible to minimize possible effects of distinct forest structure, between altitudes, on FRB.

The RLD for each sample was calculated by dividing root length by volume of the sample (Soethe et al 2006). Depth distributions for each site were fitted to a model of vertical root distribution based on the asymptotic equation $\mathrm{Y}=-1 \beta^{\mathrm{d}}$, where $\mathrm{Y}$ is the cumulative root fraction (a proportion between 0 and 1) from the soil surface to depth $\mathrm{d}$ (in centimeters) and $\beta$ is the fitted extinction coefficient (Gale \& Grigal 1987). Since $\beta$ is the fitted parameter, it provides a simple numerical index of rooting distribution (Gale \& Grigal 1987) where high values correspond to a greater proportion of roots at depth and low values have a greater proportion of roots near the soil surface (Jackson et al. 1996). For each depth, significant differences of RLD and FRB were assessed by student's t-test and differences of $\beta$ between altitudes and seasons were assessed by Two-way ANOVA with post hoc Tukey's test (R software version 2.11.1, 2010, http://www.R-project.org). SYSTAT 7.0 was used to estimate $\beta$.

\section{Results}

The Montane forest had the shallowest rooting profiles in the dry and wet seasons ( $\beta=0.77$ and 0.56 , respectively), with $79.41 \%$ of roots occurring in the top $5 \mathrm{~cm}$ of soil in the dry season and $94.38 \%$ in wet season (Table 1). On the other hand, the Lowland forest had the deepest rooting profiles ( $\beta=0.81$ and 0.74 ) with $77.5 \%$ of roots occurring in the top $5 \mathrm{~cm}$ of soil in the dry season and $84 \%$ in wet season (Table 1). From dry to wet season there was a trend of increase of shallow roots in both sites as indicated by the decrease in $\beta$ values and $\%$ of roots occurring in the top $5 \mathrm{~cm}$ of soil.

The Montane forest had higher FRB in the 0-5 soil layer in both seasons and in the 5-10 layer in the dry season (Figure 2a), while for others depths there were no differences between altitudes. Seasonal differences in FRB were observed only in the montane site in the 5-10 and 10-20 layers, with lower values in the wet season (Figure 2b). The total FRB in the top $30 \mathrm{~cm}$ of the soil in the dry and wet season was: 334.53 and $219.11 \mathrm{~g} \mathrm{~m}^{-2}$ for the Lowland forest and 875.22 and $451.04 \mathrm{~g} \mathrm{~m}^{-2}$ for the Montane Forest. At both altitudes and seasons, FRB was highest in the 0-5 layer (Figure 2) although higher values were observed at the Montane forest. The variation of FRB between altitudes in the $0-5 \mathrm{~cm}$ was 3.2 fold in the dry and 2.2 fold in the wet season. In the $5-10 \mathrm{~cm}$ in the dry season, the

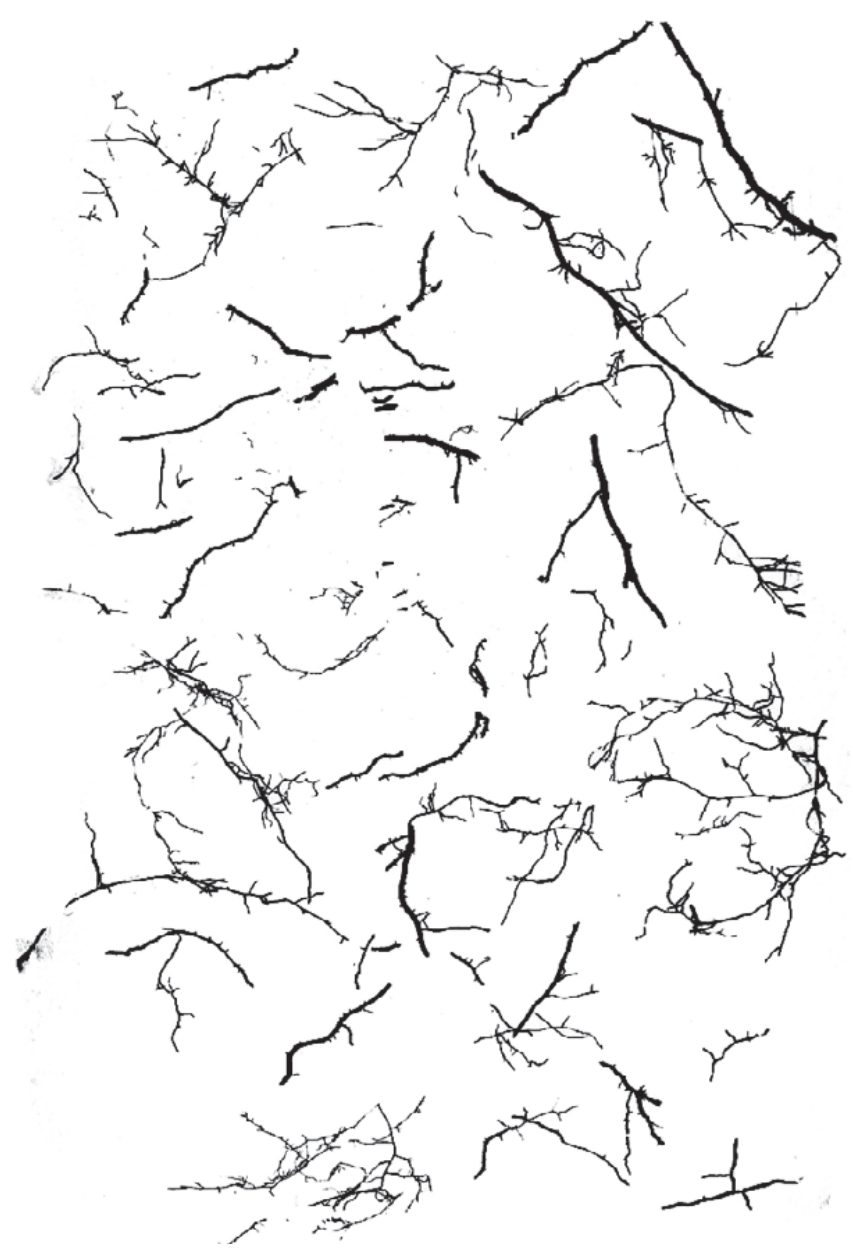

Figure 1. Digital image of fine roots stained with methylen blue used to estimate root length and surface area using Rootedge software version 2.3. 
FRB variation between altitudes was 2.5 fold. The differences of FRB observed between altitudes did not change when considering the FRB/AGB ratio. Considering only the 0-5 soil layer, where differences between altitudes were pronounced, the Montane forest showed higher FRB/AGB values (1.80 and 1.23 in the dry and wet season, respectively) while the Lowland site showed 0.74 and 0.60 in the dry and wet season, respectively.

RLD was also highest in montane forest in the top $5 \mathrm{~cm}$ of soil in both seasons where variation between altitudes was 4.7 -fold in dry and 2.5-fold in wet season (Figure $3 \mathrm{~b}$ ). Higher RLD values were also observed in montane forest in the $5-10 \mathrm{~cm}$ in dry (1.8-fold) and wet season (2.0-fold). In the $20-30 \mathrm{~cm}$ in the dry season, RLD was 3.2-fold higher than lowland forest (Figure 3a). Seasonally, both altitudes showed higher values in the wet season only in the $0-5 \mathrm{~cm}$ layer (Figure 3b).

\section{Discussion}

The higher values of RLD and FRB at the $0-5 \mathrm{~cm}$ layer at the Montane forest associated to the low $\beta$ values indicate that the highest potential for nutrient and water uptake is in the top soil. The higher investment in fine roots at Montane forests, especially in shallow soil layers to $0-5 \mathrm{~cm}$ depth, is probably a response to maximize nutrient uptake under the lower decomposition rates (Bruijnzeel \& Veneklaas
1998). The higher FRB, RLD and more superficial distribution of fine roots, especially at Montane forests, may improve nutrients uptake that are leached from the canopy (Stewart 2000), litterfall, stemflow and throughfall (Cavalier 1992). Our results are in accordance to those observed by Sousa Neto (2008), who found increases of FRB with altitude in shallow soil layers at the Atlantic Rain Forest. In fact, studies performed in our sites show that litter accumulation is higher and litterfall is lower at the Montane site, what is also related to the lower decomposition rates (Sousa Neto 2008, Martins 2010). The lower decomposition rates, and the higher content of organic matter at the Montane site (Martins 2010) indicate a higher availability of more organic forms of nitrogen, which could be related to the higher investment in fine roots at $0-5 \mathrm{~cm}$ (Näsholm et al. 2009). It was not possible evaluate if the higher RLD and FRB values observed at the Montane forest were due to high fine root production or high fine root longevity. However, lower air and soil temperatures, as observed at the Montane forest (Sousa Neto 2008), are associated to lower respiration rates reducing root turnover (Gill \& Jackson 2000) and increasing root longevity (Graefe et al. 2008). In fact, as pointed out by Sousa Neto (2008), at the Montane forest, the higher amounts of live and dead fine roots, associated to lower soil-atmosphere emissions of nitrous oxide $\left(\mathrm{N}_{2} \mathrm{O}\right)$, suggest a lower production, mortality and, consequently, lower decomposition rates of fine roots.

Table 1. Mean values of $\beta \pm$ standard deviation for each site/season (associated $\mathrm{R}^{2}$ values) according to the Gale and Grigal model (1987) and percentage of fine root biomass (FRB) in the upper $5 \mathrm{~cm}$ of the soil.

\begin{tabular}{ccccc}
\hline Season & Site & $\boldsymbol{\beta}$ & $\mathbf{R}^{2}$ & \% Root biomass in upper 5 cm \\
\hline \multirow{2}{*}{ Dry } & Lowland & $0.81 \pm 0.06^{\mathrm{a}}$ & 0.75 & 77.49 \\
& Montane & $0.77 \pm 0.11^{\mathrm{a}}$ & 0.77 & 79.41 \\
\multirow{2}{*}{ Wet } & Lowland & $0.74 \pm 0.09^{\mathrm{a}}$ & 0.77 & 84.01 \\
& Montane & $0.56 \pm 0.07^{\mathrm{b}}$ & 0.60 & 94.38 \\
\hline
\end{tabular}
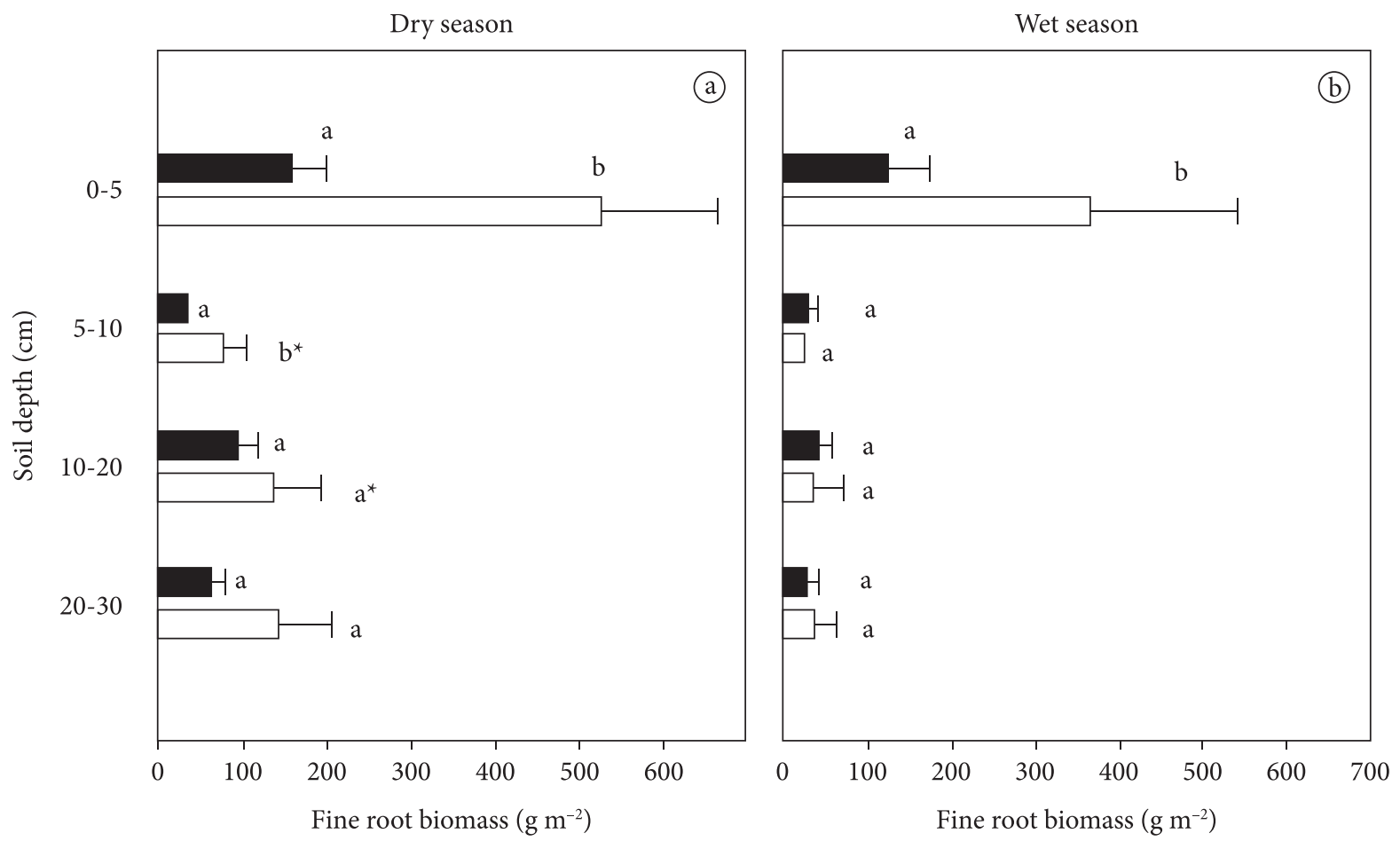

Figure 2. Variation of fine root biomass in soil profile between Lowland ( $\mathbf{\square})$ and Montane forest ( $\square$ ) and seasons. Lower case letters indicate significant differences between altitudes in each depth (student's $t$-test; $\mathrm{p}<0.05$ ); asterisks indicate significant differences between seasons in each depth (student's $t$-test; $\mathrm{p}<0.05$ ). 

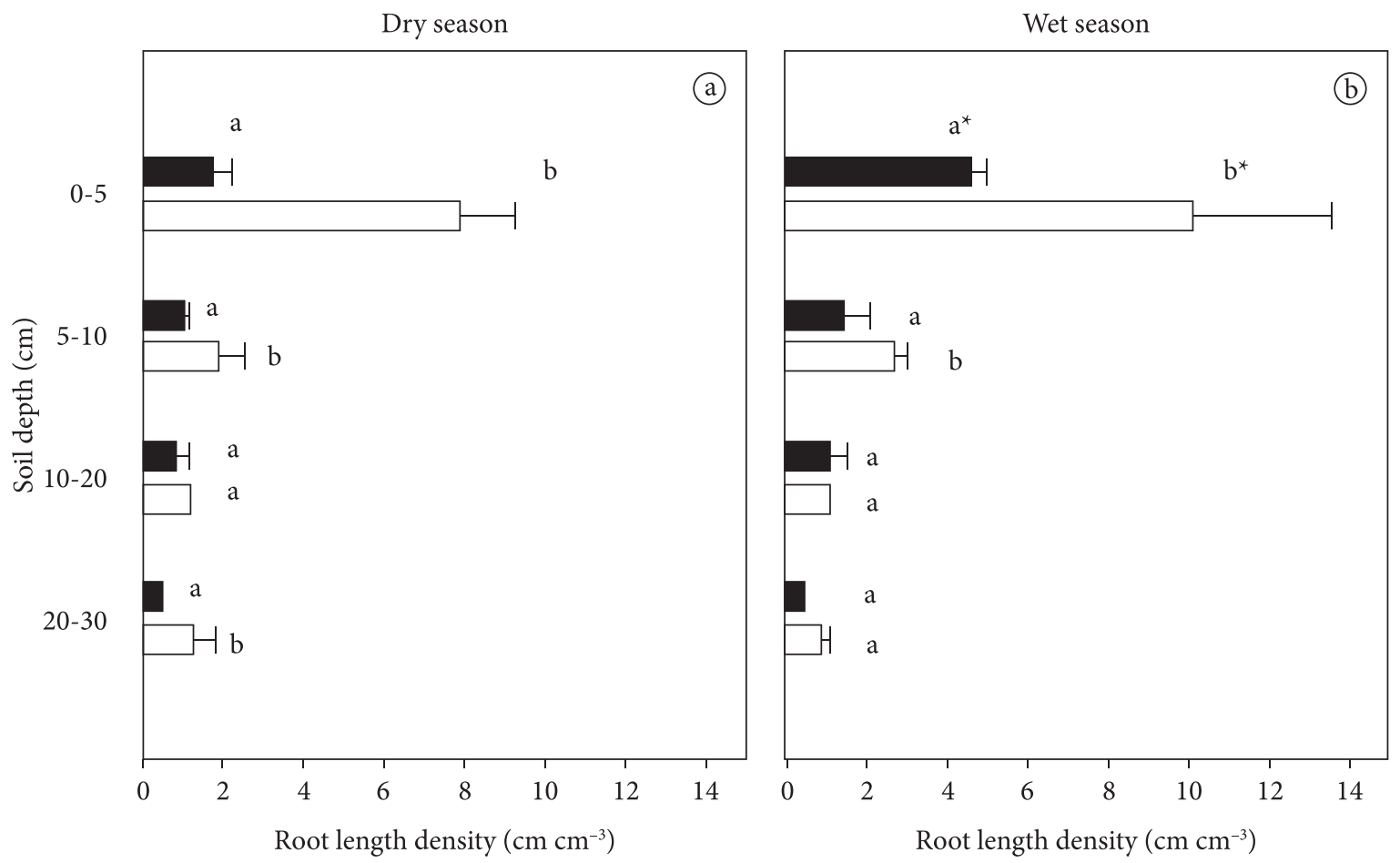

Figure 3. Variation of root length density in soil profile, between Lowland ( $\mathbf{a})$ and Montane forest ( $\square$ ) and seasons. Lower case letters indicate significant differences between altitudes in each depth (student's $t$-test; $\mathrm{p}<0.05$ ); asterisks indicate significant differences of altitude between seasons in each depth (Student's $t$-test; $\mathrm{p}<0.05$ ).

Our FRB data in the top $30 \mathrm{~cm}\left(219.11-875.22\right.$ g.m $\left.{ }^{-2}\right)$ are within the range reported for other tropical forests from 150 to $\sim 1100$ g.m $\mathrm{m}^{-2}$ (Cavelier et al. 1996, Herbert \& Fownes 1999, Yavitt \& Wright 2001, Hertel et al. 2003, Leuschner et al. 2007). In fact, Jackson et al. (1997) reported an average value of 330 g. $\mathrm{m}^{-2}$ for tropical forests. Unfortunately, we did not evaluate deeper soil layers below $30 \mathrm{~cm}$ due to shallow rock bed. However, the differences and vertical distribution in the top $30 \mathrm{~cm}$ of soil between the Lowland and the Montane forest may affect water absorption by plants and, consequently, transpiration and evapotranspiration (Williams et al. 1998). However, the linkages between fine roots, plant water use and evapotranspiration remain to be answered in future studies to be conducted at the Atlantic rain forest.

Although we did not find differences in the seasonal variation of FRB for each depth, except at the Montane forest in the depths of 5-10 and 10-20 cm, there was a trend of lower FRB in the wet season especially when considering the whole soil profile. According to Cavelier (1992), low FRB values are associated to more carbon allocation aboveground during the growing season what could decrease the fine root production. In addition, higher water availability during wet season might promote oxygen deficiency (Soethe et al. 2006, Graefe et al. 2008) what may contribute to accelerate root death and decomposition rates (Yavitt \& Wright 2001). Our RLD data in both sites are similar to those observed by Soethe et al. (2006) along an altitudinal gradient in Ecuador. In our study, the increase of RLD from the dry to the wet season, especially at the top soil as also indicated by lower $\beta$ values, may improve the nutrient and water uptake compensating the lower FRB values. In fact, it has been observed that the density of fine roots increased with soil water content and nutrient availability without changes in FRB (Yavitt \& Wright 2001), what is also associated to changes in root anatomy to invest in length maintaining similar biomass (Hill et al. 2006).

Despite the indicative that higher FRB and RLD at the Montane site are related to lower decomposition rates, we should take into account non-mutually exclusive hypothesis to explain the observed pattern. Although we observed increases in RLD and FRB in forests from $\sim 100$ to $\sim 1000 \mathrm{~m}$ above sea level, in accordance to changes in fine root parameters that are usually observed along altitudinal gradients in tropical mountains (Leuschner et al. 2007), multiple factors along altitudinal gradients, such as lower partial pressure of oxygen, lower temperatures, reductions in tree size and species abundance, may also affect the investment in fine roots in higher altitudes (Soethe et al. 2006, Leuschner et al. 2007, Graefe et al. 2008). Thus, despite the higher FRB/AGB, at the Montane forest, we can not disregard the alternative hypothesis to explain this pattern. Differences in forest structure, phytosociology and species composition might be co-factors affecting the differences of fine root parameters (Leuschner et al. 2007) between Lowland and Montane forest. For instance, considering the lower FRB/AGB at the Lowland forest, it is important take into account the effect of anthropogenic disturbances on our results, since the Lowland forest experienced logging and different land uses that can reduce the stem density (Alves et al. 2010) and, consequently, promote reductions in FRB and RLD. Thus, the higher FRB and RLD at the Montane forest may be related to the total stem density $\left(\mathrm{ha}^{-1}\right)$ and/or aboveground biomass, which are higher at the Montane forest in comparison to the Lowland forest (Alves et al. 2010). In addition, the high density of bamboos (3813 culms.ha $^{-1}$ ), that are present only at the Montane site (Padgurschi 2010), may also contribute to the higher FRB and RLD.

In conclusion, despite limitations to our understanding about the possible causes to the increase in fine root parameters with altitude, it was possible to draw some important implications regarding the differences in FRB and RLD between altitudes. The main differences in fine root parameters between altitudes were related to the $0-5 \mathrm{~cm}$ soil layer, suggesting that differentiation of both forests in terms of ecosystem functioning belowground at the Atlantic Rain Forest is not dependent on deep layers but to a restricted and shallow soil compartment. Despite the relevance of FRB to describe processes 
related to carbon dynamics, the variation of RLD between seasons, independently of variations in FRB, indicates that RLD is a better descriptor for studies characterizing the potential of water and nutrient uptake at the Atlantic Rain Forest. Thus, the differences in RLD between altitudes rather than FRB, within the context of resource use, should be considered in studies about plant establishment, seedling growth and population dynamics at the Atlantic Rain Forest. At the ecosystem level, the seasonal variations of RLD may improve our understanding of the functioning of Atlantic rain forest in terms of the biogeochemical fluxes in a possible scenario of climate change and environmental changes.

\section{Acknowledgements}

This paper derives from B.H.P. Rosado's doctoral thesis. We are grateful to Renato Belinello, Roseli Costa, Ewerton Manarin, Mauro Brum and Cleiton Eller for help in field work and laboratory. Sincere thanks goes to Willis Gwenzi (University of Western Australia) for useful discussions, Luis Fernando Martins for help us with the root washing system and Flavio Maës dos Santos, Eduardo Arcoverde de Mattos, Sergio Tadeu Meirelles and two anonymous reviewers for comments and suggestions. The authors were supported by grants from $\mathrm{CNPq}$ and the Biota-FAPESP Program - Projeto Temático Gradiente Funcional (03/12595-7). COTEC/IF 41.065/2005 and IBAMA/CGEN 093/2005.

\section{References}

ALVES, L.F., VIEIRA, S.A., SCARANELLO, M.A., CAMARGO, P.B., SANTOS, F.A.M., JOLY, C.A. \& MARTINELLI, L.A. 2010. Forest structure and live aboveground biomass variation along an elevational gradient of tropical Atlantic moist forest (Brazil). For. Ecol. Manage. 260:679-691. http://dx.doi.org/10.1016/j.foreco.2010.05.023

BOUMA, T.J., NIELSEN, K.L. \& KOUTSTAAL, B. 2000. Sample preparation and scanning protocol for computerised analysis of root length and diameter. Plant Soil 218:185-196. http://dx.doi. org/10.1023/A:1014905104017

BRUIJNZEEL, L.A. \& VENEKLAAS, E.J. 1998. Climatic conditions and tropical montane forest productivity: the fog has not lifted yet. Ecology 79:3-9. http://dx.doi.org/10.1890/0012-9658(1998)079[0003:CCATM F]2.0.CO;2

CAVELIER, J. 1992. Fine-root biomass and soil properties in a semideciduous and a lower montane rain forest in Panama. Plant Soil 142:187-201. http:// dx.doi.org/10.1007/BF00010965

GALE, M.R. \& GRIGAL, D.K. 1987. Vertical root distributions of northern tree species in relation to successional status. Can. J. For. Res. 17:829834. http://dx.doi.org/10.1139/x87-131

GILL, R.A. \& JACKSON, R.B. 2000. Global patterns of root turnover for terrestrial ecosystems. New Phytolog. 147:13-31. http://dx.doi. org/10.1046/j.1469-8137.2000.00681.x

GORDON, W.S. \& JACKSON, R.B. 2000. Nutrient concentrations in fine roots. Ecology 81:275-280. http://dx.doi.org/10.1890/00129658(2000)081[0275:NCIFR]2.0.CO;2

GRAEFE, S., HERTEL, D. \& LEUSCHNER, C. 2008. Estimating Fine Root Turnover in Tropical Forests along an Elevational Transect using Minirhizotrons. Biotropica 40:536-542. http://dx.doi.org/10.1111/j.17447429.2008.00419.x

HERBERT, D.A. \& FOWNES, J.H. 1999. Forest productivity and efficiency of resource use across a chronosequence of tropical montane soils. Ecosystems 2:242-254. http://dx.doi.org/10.1007/s100219900072

HERTEL, D., LEUSCHNER, C. \& HÖLSCHER, D. 2003. Size and structure of fine root systems in old-growth and secondary tropical montane forests (Costa Rica). Biotropica 35:143-153.
HILL, J., SIMPSON, R., MOORE, A. \& CHAPMAN, D. 2006. Morphology and response of roots of pasture species to phosphorus and nitrogen nutrition. Plant Soil 286:7-19. http://dx.doi.org/10.1007/s11104-0060014-3

HIMMELBAUER , M.L., LOISKANDL, W. \& KASTANEK, F. 2004. Estimating length, average diameter and surface area of roots using two different Image analyses systems. Plant Soil 260:111-120. http://dx.doi. org/10.1023/B:PLSO.0000030171.28821.55

JACKSON, R., CANADELL, J., EHLERINGER, J.R., MOONEY, H.A., SALA, O.E. \& SCHULZE, E.D. 1996. A global analysis of root distributions for terrestrial biomes. Oecologia 108:389-411. http://dx.doi. org/10.1007/BF00333714

JACKSON, R.B., MOONEY, H.A. \& SCHULZE, E.D. 1997. A global budget for fine root biomass, surface area, and nutrient contents. Proc. Nat. A. Scienc. 94:7362-7366. http://dx.doi.org/10.1073/pnas.94.14.7362

JOLY, C.A., AIDAR, M.P.M., KLINK, C.A., MCGRAPH, D.G., MOREIRA, A.G., MOUTINHO, P., NEPSTAD, D.C., OLIVEIRA, A.A., POTT, A. \& SAMPAIO, E.V.S.B. 1999. Evolution of the Brazilian phytogeography classification systems: implications for biodiversity conservation. Cienc. Cult. 51:331-348.

KASPAR, T.C. \& EWING, R.P. 1997. ROOTEDGE: Software for measuring root length from desktop scanner images. Agron. J. 89:932-940. http:// dx.doi.org/10.2134/agronj1997.00021962008900060014x

LEUSCHNER, C., MOSER, G., BERTSCH, C., RÖDERSTEIN, M. \& HERTEL, D. 2007. Large altitudinal increase in tree root/shoot ratio in tropical mountain forests of Ecuador. Basic Appl. Ecol. 8:219-230. http:// dx.doi.org/10.1016/j.baae.2006.02.004

MARTINS, L.F.D.S. 2002. Configuração do sistema radicular das árvores de Eucalyptus grandis em resposta à aplicação de doses crescentes de biossólido. Dissertação de Mestrado, Universidade de São Paulo, Piracicaba.

MYERS, N., MITTERMEIER, R.A., MITTERMEIER, C.G., FONSECA, G.A.B. \& KENT, J. 2000. Biodiversity hotspots for conservation priorities. Nature 403:853-858. PMid:10706275. http://dx.doi. org/10.1038/35002501

NÄSHOLM, T., KIELLAND, K. \& GANETEG, U. 2009. Uptake of organic nitrogen by plants. New Phytolog. 182:31-48.

NEPSTAD, D.C., CARVALHO, C., DAVIDSON, E., JiPP, P.H., LEFEBVRE, P., NEGREIROS, G.H., DA SILVA, E.D., STONE, T.A., TRUMBORE, S.E. \& VIEIRA, S.A. 1994. The role of deep roots in the hydrological and carbon cycles of Amazonian forests and pastures. Nature 372:666-669. http://dx.doi.org/10.1038/372666a0

PADGURSCHI, M.C.G. 2010. Composição e estrutura arbórea de um trecho de Floresta Ombrófila Densa Montana com taquaras na Mata Atlântica. Dissertação de Mestrado, Universidade Estadual de Campinas, Campinas.

PERSSON, H. 1978. Root dynamics in a young Scots pine stand in central Sweden. Oikos 30:508-519. http://dx.doi.org/10.2307/3543346

ROSADO, B.H.P., OLIVEIRA, R.S. \& AIDAR, M.P.M. 2010. Is leaf water repellency related to vapor pressure and crown exposure in tropical forests? Acta Oecolog. 36:645-649. http://dx.doi.org/10.1016/j. actao.2010.10.001

SOETHE, N., LEHMANN, J. \& ENGELS, C. 2006. The vertical pattern of rooting and nutrient uptake at different altitudes of a south Ecuadorian montane forest. Plant Soil 286:287-299. http://dx.doi.org/10.1007/ s11104-006-9044-0

SOUSA NETO, E.R. 2008. Perdas de nitrogênio pela emissão de óxido nitroso $\left(\mathrm{N}_{2} \mathrm{O}\right)$ e sua relação com a decomposição da serapilheira e biomassa de raízes na floresta de Mata Atlântica. Dissertação de Mestrado, Universidade de São Paulo, Piracicaba.

STEWART, C.G. 2000. A test of nutrient limitation in two tropical montane forests using root in growth cores. Biotropica 32:369-373. 
WILLIAMS, M., MALHI, Y., NOBRE, A.D., RASTETTER, E.B., GRACE, J. \& PEREIRA, M.G.P. 1998. Seasonal variation in net carbon exchange and evapotranspiration in a Brazilian rain forest: a modelling analysis. Planr Cell Environ. 21:953-968. http://dx.doi.org/10.1046/j.13653040.1998.00339.x

YAVITT, J.B. \& WRIGHT, S.J. 2001. Drought and Irrigation Effects on Fine Root Dynamics in a Tropical Moist Forest, Panama. Biotropica 33:421-434.
ZEPPEL, M.J.B., MURRAY, B.R., BARTON, C. \& EAMUS, D. 2004. Seasonal responses of xylem sap velocity to VPD and solar radiation during drought in a stand of native trees in temperate Australia. Funct. Plant Biol. 31:461-470. http://dx.doi.org/10.1071/FP03220

ZOBEL, R.W., KINRAIDE, T.B. \& BALIGAR, V.C. 2007. Fine root diameters can change in response to changes in nutrient concentrations. Plant Soil 297:243-254. http://dx.doi.org/10.1007/s11104-007-9341-2

Received 16/02/2011 Revised 28/08/2011 Accepted 05/09/2011 